\title{
HUBUNGAN PERSEPSI BODY IMAGE DENGAN ASUPAN LEMAK DAN KOMPOSISI LEMAK TUBUH PADA SISWI DI MAN 2 SURAKARTA
}

\section{THE CORRELATION OF BODY IMAGE PERCEPTION WITH FAT INTAKE AND BODY FAT COMPOSITION IN ADOLESCENT FEMALE MAN 2 SURAKARTA}

\author{
Nuraeni Chairi Nisa ${ }^{1}$, Luluk Ria Rakhma ${ }^{2}$ \\ Program Studi Ilmu Gizi Fakultas Ilmu Kesehatan Universitas Muhammadiyah Surakarta
}

(Alamat Respondensi : nuraenichairi@gmail.com / 089-520-756-126)

\begin{abstract}
ABSTRAK
Masa remaja merupakan masa transisi dari anak-anak ke dewasa ditandai oleh berbagai perubahan emosi, psikis dan perubahan fisik. Perubahan fisik akan membuat remaja mulai memperhatikan bentuk tubuhnya sehingga muncul persepsi body image Persepsi body image negatif (ketidakpuasan terhadap tubuh) akan mengurangi asupan lemak. Persepsi body image negatif rentan terjadi pada remaja putri karena penambahan lemak tubuh. Tujuan penelitian untuk mengetahui hubungan persepsi body image dengan asupan lemak dan komposisi lemak tubuh pada siswi di MAN 2 Surakarta. Jenis penelitian adalah observasional dengan pendekan cross-sectional. Teknik pengambilan sampel menggunakan proportional random sampling. Sampel yang digunakan sebanyak 52 siswi. Data persepsi body image diperoleh menggunakan MBSRQ-AS (Multidimensional Body-Self Relations Questionnaire-Appearance Scale). Data asupan lemak diperoleh menggunakan formulir SQFFQ (Semi Quantitative Food Frequency) selama 1 bulan terakhir. Data komposisi lemak tubuh diperoleh menggunakan BIA (Bioelectrical Impedance Analysis). Hasil sebanyak 51,9\% subyek memiliki persepsi body image positif, sebanyak $76,9 \%$ subyek memiliki asupan lemak baik dan sebanyak $67,3 \%$ subyek memiliki komposisi lemak tubuh kategori sedang. Tidak ada hubungan persepsi body image dengan asupan lemak (p value 0,666 ). Tidak ada persepsi body image dengan komposisi lemak tubuh ( $\mathrm{p}$ value 0,169$)$.
\end{abstract}

Kata Kunci: Asupan Lemak, Komposisi Lemak Tubuh, Persepsi Body Image.

\begin{abstract}
Adolescent is a period of transition from child to adult characterized by various emotional, psychological and physical changes. This physical change make adolescent start to see body shape. Perceptions of negative body image (dissatisfaction with the body) will reduce fat intake. Perception of negative body image is susceptible to adolescent female due to the addition of body fat. This study aimed to determine the association perceptions body image with fat intake and body fat composition of adolescent female at MAN 2 Surakarta. Method is an observational research with cross-sectional approach. Respondent were selected with proportional random sampling. The samples were 52 female students. Body image perceptions obtained from MBSRQ-AS (Multidimensional Body-Self Relations Questionnaire-Appearance Scale). Fat intake data obtained from SQFFQ (Semi Quantitative Food Frequency) form at least a month. Body fat composition obtained from measurement using BIA (Bioelectrical Impedance Analysis). Result as many as 51,9\% subjects have perceptions of positive body image, As many as 76,9\% subjects have good fat intake and as many as $67,3 \%$ subjects have middle body fat compotition. There was no association of perceptions of body image with fat intake ( $p$ value $=0,666$ ) and there was no association of perceptions of body image with body fat composition ( $\mathrm{p}$ value $=0,169)$.
\end{abstract}

Keywords: Body Fat Composition, Body Image Perception, Fat Intake.

\section{PENDAHULUAN}


Masa remaja merupakan masa transisi dari anak-anak ke dewasa yang ditandai oleh berbagai perubahan emosi, psikis dan perubahan fisik. ${ }^{1}$ Perubahan fisik ini akan membuat remaja mulai memperhatikan bentuk tubuhnya. ${ }^{2}$ Banyak remaja yang tidak puas dengan berat badan dan bentuk tubuhnya. Body image adalah gambaran seseorang mengenai ukuran dan bentuk tubuhnya sendiri, ada dua macam body image yaitu body image positif (persepsi seseorang puas akan tubuhnya) dan body image negatif (persepsi seseorang yang tidak puas akan tubuhnya). ${ }^{3}$

Terdapat perbedaan kepuasaan bentuk tubuh antara remaja putri dan remaja putra dimana remaja lebih cenderung puas dengan bentuk tubuhnya dibanding remaja putri. Remaja putra puas terhadap tubuhnya apabila massa otot meningkat sedangkan remaja putri tidak puas dengan penambahan lemak pada tubuhnya. ${ }^{4}$ Persepsi remaja tentang body image dapat menentukan pola makan. ${ }^{5}$ Terdapat hubungan positif antara persepsi body image terhadap frekuensi makan dimana apabila hasil body image negatif maka akan cenderung mengurangi frekuensi makan. ${ }^{3}$ Hasil penelitian Ruslie dan Darmadi (2012) menunjukkan bahwa terdapat hubungan antara body image dengan asupan makan, responden dengan body image negatif akan mengurangi jumlah asupan makan dan menghindari makanan yang tinggi lemak. ${ }^{6}$

Lemak merupakan makronutrien yang menghasilkan energi paling banyak, pada 1 gram lemak mengandung $9 \mathrm{kkal}$. Lemak memiliki fungsi antara lain pembentukan komponen membran sel, hormon dan vitamin larut lemak. ${ }^{7}$ Konsumsi lemak berlebih akan disimpan pada jaringan bawah kulit. ${ }^{8}$

Penelitian Lingga (2011) mendapatkan hasil terdapat hubungan persepsi bentuk tubuh dengan status gizi yang mana remaja putri yang memiliki persepsi bentuk tubuh positif belum tentu status gizinya baik, hal ini karena terdapat remaja putri yang memiliki status gizi normal tetapi memiliki persepsi tubuh negatif. Remaja putri mengganggap bahwa bentuk tubuhnya lebih kurus atau gemuk namun ternyata status gizi tergolong normal. ${ }^{9}$ Penelitian Ranasinghe, dkk (2013) menyatakan bahwa status gizi dengan pengukuran IMT berkorelasi dengan persen lemak tubuh, yang mana semakin tinggi nilai IMT maka semakin tinggi lemak tubuh. ${ }^{10}$

Hasil Riskesdas (2013) menunjukkan bahwa status gizi lebih remaja berumur lebih dari 15 tahun sebesar 7,3\% dan status gizi kurang sebesar 9,4\% ${ }^{11}$, sedangkan menurut Riskesdas (2010) prevalensi gizi lebih sebesar $1,4 \%$ dan status gizi kurang sebesar $7,1 \%{ }^{12}$. Sehingga terjadi peningkatan prevalensi status gizi kurang dan status gizi lebih pada remaja. Gizi lebih pada remaja akan menimbulkan masalah penyakit degeneratif seperti hipertensi. Gizi lebih terjadi akibat penimbunan lemak yang berlebihan dalam jaringan lemak tubuh, status gizi akan mempengaruhi komposisi tubuh seseorang. ${ }^{13}$

Menurut hasil penelitian pendahuluan di MAN 2 Surakarta dari 10 siswi didapatkan hasil sebanyak 40\% siswi memiliki persepsi body image negatif sedangkan untuk asupan lemak didapatkan hasil sebanyak $20 \%$ asupan lemak tergolong berlebih, sebanyak $60 \%$ asupan lemak tergolong cukup dan sebanyak 20\% termasuk kategori asupan kurang. Berdasarkan lokasi MAN 2 Surakarta terletak 
di pusat kota sehingga akses media massa cukup tinggi, lingkungan perkotaan yang lebih cenderung rawan terhadap pengaruh mode yang tren saat ini, dan MAN 2 Surakarta dekat dengan pusat perbelanjaan seperti mall sehingga ditemukan banyak penjual makanan cepat saji (fast food) di area sekolah. Berdasarkan uraian tersebut penulis tertarik untuk mengetahui hubungan persepsi body image terhadap asupan lemak dan komposisi lemak tubuh siswi MAN 2 Surakarta

\section{BAHAN DAN METODE}

Jenis penelitian ini termasuk penelitian observasional dengan rancangan crossectional. Waktu penelitian ini dilaksanakan pada bulan Januari 2018. Lokasi penelitian dilakukan di MAN 2 Surakarta. Populasi dari penelitian ini adalah seluruh siswi MAN 2 Surakarta sebanyak 196 siswi. Teknik pengambilan sampel menggunakan proportional random sampling dan didapatkan jumlah sampel sebanyak 52 sampel.

Data persepsi body image diperoleh dengan menggunakan kuesioner $M B S R Q-A S$ (Multidimensional Body-Self Relations Questionnaire-Appearance Scale) yang terdiri dari evaluasi penampilan, orientasi penampilan, kepuasan terhadap bagian tubuh, kecemasan menjadi gemuk dan pengkategorian ukuran tubuh. Kuesioner MBSRQ-AS (Multidimensional Body-Self Relations Questionnaire-Appearance Scale) terdiri dari 34 soal dengan alpha cronbach 0,74. ${ }^{14}$ Kategori persepsi body image negatif $<61,6$ dan persepsi body image positif $\geq 61,6$. Data asupan lemak dengan menggunakan kuesioner SQFFQ (Semi Quantitative Food Frequency) selama 1 bulan terakhir dengan alat bantu food picture. Kategori asupan lemak dikatakan kurang $<80 \%$ AKG, baik $80-110 \%$ AKG, lebih $>110 \%$ AKG. Data komposisi lemak tubuh diperoleh dari pengukuran komposisi lemak tubuh dengan menggunakan alat BIA (Bioelectrical Impedance Analysis) merk Tanita. Pengukuran yang dilakukan sebanyak tiga kali lalu hasil dirata-rata menjadi persentase komposisi lemak tubuh. Kategori komposisi lemak tubuh rendah $<17 \%$, sedang $17-30 \%$, tinggi $>30 \%$.

\section{HASIL}

\section{Usia}

Tabel 1 menunjukkan sebagian besar responden berusia 15 tahun yaitu sebesar 55,8\% dan hanya $1,9 \%$ yang berusia 17 tahun.

\section{Persepsi Body Image}

Tabel 2 menunjukkan bahwa persepsi body image positif pada siswi MAN 2 Surakarta sebesar $48,1 \%$ dan persepsi body image negatif sebesar 51,9\%

\section{Asupan Lemak}

Tabel 3 menunjukkan bahwa asupan lemak terbagi kedalam tiga kategori yaitu asupan lemak kategori kurang, asupan lemak kategori baik dan asupan lemak kategori lebih. Pada penelitian yang 
dilakukan sebagian besar siswi memiliki kategori asupan lemak baik sebesar 76,9\%, asupan lemak kategori lebih sebesar 13,5\% dan asupan lemak kategori kurang sebesar 9,6\%.

\section{Komposisi Lemak Tubuh}

Tabel 4 menunjukkan bahwa komposisi lemak tubuh terbagi kedalam tiga kategori yaitu komposisi lemak tubuh kategori rendah, sedan dan tinggi. Pada penelitian yang dilakukan sebagian besar siswi tergolong dalam komposisi lemak tubuh kategori sedang sebesar 67,3\%, komposisi lemak tubuh kategori tinggi sebesar 26,9\% dan komposisi lemak tubuh kategori rendah sebesar 5,8\%.

\section{Hubungan Persepsi Body Image dengan Asupan Lemak}

Tabel 5 menunjukkan bahwa nilai rata-rata persepsi body image dalam penelitian ini 61,62 termasuk dalam kategori persepsi body image positif sedangkan rata-rata asupan lemak dalam penelitian ini 95,75\% termasuk dalam kategori baik.

Hasil uji statistik dengan Pearson Product Moment didapatkan nilai $\mathrm{p}=0,666(\mathrm{p}>0,05)$ maka H0 diterima sehingga tidak ada hubungan persepsi body image dengan asupan lemak pada siswi MAN 2 Surakarta. Berdasarkan Tabel 6 responden yang memiliki persepsi body image negatif dan persepsi body image positif mayoritas memiliki asupan lemak pada kategori baik, masing-masing sebesar 76,0 $\%$ dan $77,8 \%$.

\section{Hubungan Persepsi Body Image dengan Komposisi Lemak Tubuh}

Tabel 7 menunjukkan bahwa nilai rata-rata persepsi body image dalam penelitian ini 61,62 termasuk dalam kategori persepsi body image positif sedangkan rata-rata komposisi lemak dalam penelitian ini 26,73\% termasuk dalam kategori sedang. Hasil uji statistik dengan Pearson Product Moment didapatkan nilai $\mathrm{p}=0,169(\mathrm{p}>0,05)$ maka $\mathrm{H} 0$ diterima sehingga tidak ada hubungan persepsi body image dengan komposisi lemak tubuh pada siswi MAN 2 Surakarta. Berdasarkan Tabel 8 sebagian besar responden yang memiliki persepsi body image negatif dan persepsi body image positif tergolong dalam kategori komposisi lemak tubuh sedang yaitu sebesar 56,0\% dan 77,8\%.

\section{PEMBAHASAN}

\section{Usia}

Menurut Widyastuti (2009) terdapat tiga tahapan remaja yaitu fase remaja awal usia 10-12 tahun, fase remaja tengah usia 13-15 tahun dan fase remaja akhir 16-19 tahun. ${ }^{15}$ Masa remaja disebut juga masa pubertas dimana perkembangan fisik berlangsung cepat sehingga menyebabkan remaja sangat memperhatikan bentuk tubuhnya dan akan membangun citra tubuh atau body image. ${ }^{16}$

Selain permasalahan citra tubuh (body image), remaja pun rentan terhadap perubahan kebiasaan makan seperti meal skipping, penerapan diet yang salah, lebih sering makan di luar rumah khususnya konsumsi fast food dan makanan tinggi energi dan tinggi lemak. ${ }^{17}$ Pertumbuhan fisik yang terjadi pada masa remaja adalah pertambahan berat badan dan tinggi badan. Remaja putri mengalami 
perubahan drastis pada komposisi lemak tubuh sepanjang masa pubertas. Meningkatnya komposisi lemak tubuh pada remaja putri berguna untuk pertumbuhan dan perkembangan seksualnya. ${ }^{18}$

\section{Tabel 1. Usia}

\begin{tabular}{ccc}
\hline Usia & n & \% \\
\hline 15 & 29 & 55,8 \\
16 & 22 & 42,3 \\
17 & 1 & 1,9 \\
\hline Total & 52 & 100 \\
\hline
\end{tabular}

\section{Persepsi Body Image}

Dari penelitian yang dilakukan, responden yang memiliki body image negatif tidak puas dengan beberapa bagian tubuhnya yang terlihat besar seperti bagian paha, perut, lengan, tubuh yang terlalu gemuk dan tubuh yang kurang tinggi.

Penelitian yang dilakukan di MAN 2 Surakarta sebagian besar memiliki persepsi body image positif (51,9\%). Hasil penelitian yang dilakukan sejalan dengan penelitian yang dilakukan Anggraeni (2015) bahwa mayoritas siswi SMA Negeri 7 Surakarta tergolong dalam body image positif. ${ }^{19}$ Namun berbeda dengan penelitian Kusuma (2018) menunjukkan bahwa mayoritas siswi SMA Negeri 7 Surakarta bahwa mayoritas siswi memiliki persepsi body image negatif. ${ }^{20}$ Perbedaan hasil penelitian ini diduga disebabkan oleh responden dan waktu penelitian pun berbeda. Faktor waktu dapat mempengaruhi body image karena kemajuan media yang banyak menampilkan kriteria tubuh ideal yaitu tinggi dan langsing.

Tabel 2. Persepsi Body Image

\begin{tabular}{ccc}
\hline Persepsi Body Image & Frekuensi & Persentase (\%) \\
\hline Negatif & 25 & 48.1 \\
Positif & 27 & 51.9 \\
Total & 52 & 100.0 \\
\hline
\end{tabular}

Hasil rata-rata persepsi body image dengan membandingkan dengan penelitian Dienasari (2016); Aninda (2016); Putri (2014) yang menggunakan kuesioner Multidemensional Body Self Relation Questionnare-Appearance Scale (MBSRQ-AS) didapatkan nilai rata-rata persepsi body image di MAN 2 Surakarta sebesar 61,6. ${ }^{21,22,23}$ Penelitian yang dilakukan Dienasari (2016) yang meneliti tentang persepsi body image pada penari putri di Bogor mendapatkan hasil nilai rata-rata persepsi body image 109,07. ${ }^{21}$ Hasil berbeda ditunjukkan penelitian Aninda (2016) mendapatkan hasil nilai rata-rata skor persepsi body image $88,01 .^{22}$ Hasil penelitian Putri (2014) yang meneliti di mahasiswi Poltekkes Padang menunjukkan hasil rata-rata skor body image $66,7 .{ }^{23}$ Hasil rata-rata skor body image berbeda-beda karena umur responden dan lokasi penelitian berbeda. Nilai rata-rata persepsi body image siswi MAN 2 Surakarta lebih rendah dibanding dengan penelitian Dienasari (2016); Aninda (2016); Putri (2014) sehingga terdapat kecenderungan siswi MAN 2 Surakarta banyak yang tidak puas dengan bentuk tubuhnya. ${ }^{21,22,23}$ 
Remaja dengan persepsi body image negatif akan berperilaku makan negatif seperti selalu mempertimbangkan kalori yang dikonsumsi sehingga banyak dari remaja memiliki gangguan pemenuhan gizi yang akan berdampak ke status gizi. ${ }^{24}$

\section{Asupan Lemak}

Asupan lemak diambil dengan kuesioner Semi Quantitative Food Frequency (SQFFQ). Makanan yang sering dikonsumsi yaitu pempek, gorengan (bakwan atau mendoan), bakso, ayam, telur ayam, chiki, fried chicken, sosis, nugget dan bandeng. Makanan yang sering dikonsumsi diolah dengan cara digoreng menggunakan minyak dan minyak merupakan salah satu sumber lemak. Penambahan lemak dalam makanan dapat memberikan efek rasa lezat dan tekstur makanan menjadi lembut dan gurih. ${ }^{25}$

Tabel 3. Asupan Lemak

\begin{tabular}{ccc}
\hline Asupan Lemak & Frekuensi & Persentase (\%) \\
\hline Kurang & 5 & 9.6 \\
Baik & 40 & 76.9 \\
Lebih & 7 & 13.5 \\
Total & 52 & 100 \\
\hline
\end{tabular}

Lemak merupakan zat gizi penghasil energi terbesar lebih dari dua kali energi yang dihasilkan oleh karbohidrat dan protein. Jika asupan lemak berlebih maka tubuh akan menyimpan lemak di jaringan adiposa. ${ }^{26}$ Lemak juga dapat membantu memberikan rasa kenyang, dan sebagai alat transportasi pembawa vitamin larut lemak (vitamin A, D, E dan K). ${ }^{27}$ Dampak kekurangan asupan lemak akan berdampak pada penurunan fungsi reproduksi pada remaja perempuan seperti gangguan seperti gangguan siklus menstruasi yang terlalu lama. ${ }^{28}$

\section{Komposisi Lemak Tubuh}

Komposisi lemak tubuh adalah massa lemak yang berada dalam jaringan adiposa dan jaringan lain pada tubuh. ${ }^{29}$ komposisi lemak wanita meningkat setelah menarche dan mengalami perubahan hormonal. Menarche terjadi pada usia 10,5 - 15,5 tahun dimana terjadi penambahan lemak tubuh lebih tinggi dibandingkan sebelum menarche. Penambahan lemak akan digunakan sebagai cadangan energi selama masa kehamilan dan masa menyusui. ${ }^{30}$

Tabel 4. Komposisi Lemak Tubuh

\begin{tabular}{ccc}
\hline Komposisi Lemak & Frekuensi & Persentase (\%) \\
\hline Rendah & 3 & 5.8 \\
Sedang & 35 & 67.3 \\
Tinggi & 14 & 26.9 \\
Total & 52 & 100 \\
\hline
\end{tabular}

\section{Hubungan Persepsi Body Image dengan Asupan Lemak}

Hasil uji statistik dengan Pearson Product Moment didapatkan nilai $p=0,666(p>0,05)$ maka H0 diterima sehingga tidak ada hubungan persepsi body image dengan asupan lemak pada siswi MAN 2 Surakarta.

Tabel 5. Hubungan Persepsi Body Image dengan Asupan Lemak 


\begin{tabular}{cccccc}
\hline \multicolumn{1}{c}{ Variabel } & Mean & Minimal & Maksimal & $\begin{array}{c}\text { Standar } \\
\text { Deviasi }\end{array}$ & p value \\
\hline Persepsi Body Image & 61,62 & 45,2 & 75,6 & 6,26 & 0,666 \\
Asupan Lemak (\%) & 95,75 & 75,90 & 122,40 & 11,08 & 0,66 \\
\hline
\end{tabular}

Tidak adanya hubungan persepsi body image dengan asupan lemak sejalan dengan hasil penelitian Purba (2014) yang menyatakan tidak ada hubungan antara persepsi body image dengan konsumsi makanan sumber lemak, dimana hasil menunjukkan persepsi body image tidak berpengaruh terhadap asupan lemak, responden dengan persepsi body image negatif dan persepsi body image positif mayoritas memiliki asupan lemak kategori baik. ${ }^{31}$ Menurut Putri (2015) yang meneliti tentang faktor-faktor yang berhubungan dengan pola konsumsi siswi di Jakarta didapatkan hasil bahwa tidak ada hubungan antara body image dengan pola konsumsi siswi. Pola konsumsi yang diteliti yaitu konsumsi asupan energi, protein dan lemak. ${ }^{32}$

Hal ini sejalan dengan penelitian Sondari (2013) yang meneliti tentang body image ke konsumsi pangan menyatakan pula tidak ada hubungan antara body image terhadap asupan makan dimana menunjukkan semakin negatif persepsi body image remaja maka belum tentu remaja mengurangi konsumsi makannya. ${ }^{33}$ Berbeda dengan penelitian Chairah (2012) yang menyatakan bahwa ada hubungan antara body image dengan pola makan remaja putri yang mana semakin positif body image maka semakin baik pula pola makannya. Begitu juga sebaliknya, jika body image negatif maka semakin buruk pula pola makannya sehingga asupan yang dikonsumsi pun semakin sedikit. ${ }^{34}$

Tidak adanya hubungan body image ke asupan makan karena ada beberapa faktor yang lain yang juga mempengaruhi asupan makan seperti pendidikan, pengetahuan gizi dan sikap. ${ }^{33}$ Pengetahuan merupakan faktor penentu dari perilaku makan. Pengetahuan gizi memegang peranan yang sangat penting di dalam penggunaan dan pemilihan bahan makanan dengan baik, sehingga dapat mencapai keadaan gizi seimbang. ${ }^{35}$ Selanjutnya, Sediaoetama (2000) berpendapat bahwa semakin tinggi pengetahuan gizi seseorang semakin diperhitungkan jenis dan kualitas makanan yang dipilih untuk dikonsumsi. $^{36}$

Tabel 6. Tabulasi Silang Hubungan Persepsi Body Image dengan Asupan Lemak

\begin{tabular}{lcccccccc}
\hline \multirow{2}{*}{$\begin{array}{c}\text { Persepsi Body } \\
\text { Image }\end{array}$} & \multicolumn{9}{c}{ Asupan Lemak } & \multicolumn{2}{c}{ Total } \\
\cline { 2 - 7 } & \multicolumn{2}{c}{ Kurang } & \multicolumn{2}{c}{ Baik } & \multicolumn{2}{c}{ Lebih } & \\
\cline { 2 - 7 } & $\mathrm{n}$ & $\%$ & $\mathrm{n}$ & $\%$ & $\mathrm{n}$ & $\%$ & $\mathrm{n}$ & $\%$ \\
\hline Negatif & 3 & 12.0 & 19 & 76.0 & 3 & 12.0 & 25 & 100 \\
Positif & 2 & 7.4 & 21 & 77.8 & 4 & 14.8 & 27 & 100 \\
\hline
\end{tabular}

Sumber : Data Primer, 2018

Selain pengetahuan, komponen penting yang mempengaruhi perilaku remaja dalam pemilihan makanan adalah sikap seorang remaja. Sikap adalah reaksi atau respon seseorang yang masih tertutup terhadap suatu stimulus atau objek. Sikap akan sangat berguna bagi seseorang, sebab sikap akan mengarahkan perilaku secara langsung. Sikap positif akan menumbuhkan perilaku yang positif dan sebaliknya sikap negatif akan menumbuhkan perilaku yang negatif, seperti menolak, menjauhi, meninggalkan, bahkan sampai hal-hal merusak. ${ }^{37}$ 


\section{Hubungan Persepsi Body Image dengan Komposisi Lemak Tubuh}

Komposisi lemak tubuh responden dalam penelitian ini diambil menggunakan BIA (Bioelectrical Impedance Analysis). Hasil uji statistik dengan Pearson Product Moment didapatkan nilai p=0,169 $(\mathrm{p}>0,05)$ maka $\mathrm{H} 0$ diterima sehingga tidak ada hubungan persepsi body image dengan komposisi lemak tubuh pada siswi MAN 2 Surakarta. Walaupun secara statitistik tidak terdapat hubungan antara persepsi body image dengan komposisi lemak tubuh (lihat tabel 7), namun terdapat kecenderungan bahwa komposisi lemak tubuh tinggi banyak dimiliki oleh responden dengan persepsi body image negatif.

Tabel 7. Hubungan Persepsi Body Image dengan Komposisi Lemak Tubuh

\begin{tabular}{lccccc}
\hline \multicolumn{1}{c}{ Variabel } & $\begin{array}{c}\text { Rata- } \\
\text { rata }\end{array}$ & $\begin{array}{c}\text { Minima } \\
1\end{array}$ & Maksimal & $\begin{array}{c}\text { Standar } \\
\text { Deviasi }\end{array}$ & p value \\
\hline Persepsi Body Image & 61,62 & 45,2 & 75,6 & 6,26 & 0,169 \\
Komposisi Lemak & 26,73 & 16,0 & 44,5 & 6,40 & 0,169 \\
\hline
\end{tabular}

Tabel 8. Tabulasi Silang Hubungan Persepsi Body Image dengan Komposisi Lemak Tubuh

\begin{tabular}{lcccccccc}
\hline Persepsi & \multicolumn{4}{c}{ Komposisi Lemak Tubuh } & \multicolumn{2}{c}{ Total } \\
\cline { 2 - 7 } Body Image & \multicolumn{2}{c}{ Rendah } & \multicolumn{2}{c}{ Sedang } & \multicolumn{2}{c}{ Tinggi } & & \\
\cline { 2 - 7 } & $\mathrm{n}$ & $\%$ & $\mathrm{n}$ & $\%$ & $\mathrm{n}$ & $\%$ & $\mathrm{n}$ & $\%$ \\
\hline Negatif & 1 & 4.0 & 14 & 56.0 & 10 & 40.0 & 25 & 100 \\
Positif & 2 & 7.4 & 21 & 77.8 & 4 & 14.8 & 27 & 100 \\
\hline Sumber : Data Primer, 2018 & & & & & & &
\end{tabular}

Berdasarkan hasil penelitian Ranasinghe, dkk (2013), terdapat hubungan positif antara IMT dengan persen lemak tubuh pada wanita. Semakin tinggi IMT semakin tinggi persen lemak tubuh wanita. ${ }^{38}$ Penelitian Silva (2016) yang meneliti tentang body image terhadap status gizi pada remaja, menunjukkan hasil bahwa tidak ada hubungan ketidak puasan bentuk tubuh terhadap status gizi (IMT) ${ }^{39}$ Indeks Massa Tubuh (IMT) merupakan salah satu indeks antropometri yang menggambarkan status gizi seseorang, mencerminkan proposionalitas tubuh menurut perbandingan berat badan $(\mathrm{kg})$ dan tinggi badan $\left(\mathrm{m}^{2}\right)$, namun saat ini telah dikembangkan metode untuk melihat status gizi berdasarkan komposisi tubuh khususnya komposisi lemak. Penyusun komposisi tubuh terdiri atas massa lemak, massa otot, massa tulang dan total air dalam tubuh. ${ }^{40}$

Tidak adanya hubungan persepsi body image dengan komposisi lemak tubuh, karena body image bukan faktor langsung terhadap komposisi lemak tubuh. Body image adalah sebuah keadaan psikologi seseorang yang merupakan suatu pendapat, pemikiran dan sikap tentang bentuk serta ukuran tubuhnya. Tetapi, bukan sebuah tindakan yang bisa secara langsung untuk dilakukan. Peningkatan 
lemak tubuh dipengaruhi oleh beberapa faktor seperti aktivitas fisik yang kurang, konsumsi lemak dan konsumsi energi yang tinggi serta faktor tidak langsung seperti jenis kelamin, usia. ${ }^{41}$

Hasil penelitian Zahillah, dkk (2006) mendapatkan hasil responden yang mengalami overweight memiliki aktivitas fisik yang rendah. ${ }^{42}$ Pengeluaran energi melalui aktivitas fisik merupakan bagian yang penting dalam rangka menyeimbangkan energi yang menentukan berat badan. ${ }^{43}$ Penurunan energi expenditure melalui pengurangan aktivitas fisik memicu terjadinya peningkatan lemak tubuh. ${ }^{44}$

Penelitian Arranir, dkk (2017) didapatkan hasil terdapat hubungan asupan energi total dengan persen lemak tubuh. ${ }^{45}$ Apabila kelebihan asupan energi setelah berbagai macam proses metabolisme dalam tubuh, maka energi berlebih dalam bentuk glukosa asam lemak maupun asam amino akan diproses masing-masing secara berurutan menjadi glikogen trigliserid dan glukosa yang pada akhirnya akan disimpan dalam bentuk lemak cadangan. ${ }^{46}$

Penelitian Habibaturohmah dan Deny (2014) yang meneliti tentang konsumsi air dan asupan zat gizi terhadap persen lemak tubuh remaja putri didapatkan hasil terdapat hubungan asupan karbohidrat, asupan lemak dan konsumsi air dengan persen lemak tubuh remaja putri. ${ }^{47}$ Kebutuhan air manusia dipengaruhi oleh berat badan masing-masing individu. Apabila seseorang tergolong obesitas maka kebutuhan air pun lebih banyak. ${ }^{48}$

Faktor lain yang dapat mempengaruhi komposisi lemak tubuh yaitu asupan karbohidrat. Hasil penelitian Habibaturohmah dan Deny (2014) didapatkan hasil bahwa asupan karbohidrat mempengaruhi komposisi lemak tubuh individu. Konsumsi karbohidrat yang melebihi kebutuhan juga tidak baik bagi tubuh. ${ }^{47}$ Dalam tubuh karbohidrat disimpan dalam bentuk glikogen di hati dan otot. Remaja dengan asupan karbohidrat melebihi kebutuhan maka kapasitas hati dan otot untuk menyimpan glikogen menjadi terbatas. Sehingga kelebihan karbohidrat di hati dan otot akan disimpan dalam bentuk lemak di jaringan lemak. ${ }^{8}$

Komposisi lemak tinggi juga dipengaruhi oleh asupan lemak. Hasil penelitian Habibaturohmah dan Deny (2014) didapatkan hasil bahwa asupan lemak mempengaruhi komposisi lemak tubuh individu. ${ }^{47}$ Metabolisme lemak dalam tubuh dicerna dan menghasilkan gliserol dan asam lemak. Sebagian dibentuk kembali didalam hati dan disimpan sebagai lemak di dalam sel-sel lemak (jaringan adiposa). Sebagiannya lagi diubah menjadi asetil KoA melalui siklus TCA (Tri Carboksilat Acid) untuk menghasilkan energi. Gliserol dapat diubah menjadi glukosa atau asetil KoA untuk menghasilkan energi, namun jika siklus TCA energi tidak digunakan maka asetil KoA tidak memasuki siklus TCA melainkan digunakan untuk membentuk asam lemak. Asam lemak tersebut kemudian disimpan di jaringan lemak (adipose). ${ }^{8}$

Faktor lain yang menyebabkan peningkatan lemak tubuh yaitu jenis kelamin. Perempuan mempunyai kecenderungan lebih besar untuk mengalami gizi lebih (IMT tinggi). Remaja perempuan lebih banyak menyimpan kelebihan energinya sebagai lemak simpanan, sedangkan laki-laki menggunakan kelebihan energinya untuk mensintesis protein. Saat kematangan fisik terjadi, biasanya jumlah lemak tubuh remaja perempuan dua kali lebih banyak daripada laki-laki. ${ }^{49}$ Simpanan lemak 
wanita umumnya terdapat di daerah pinggul (pear shape), sedangkan pada pria di daerah perut (apple shape)..$^{50}$

Komposisi lemak tubuh dapat digunakan sebagai prediktor penyakit degeneratif seperti kardiovaskular, diabetes, tekanan darah tinggi dan dislipidemia. ${ }^{51}$

\section{KESIMPULAN}

Siswi MAN 2 Surakarta mempunyai persepsi body image positif sebanyak 51,9\%. Siswi MAN 2 Surakarta mempunyai asupan lemak baik sebanyak 76,9\%. Siswi MAN 2 Surakarta komposisi lemak sedang sebanyak 67,3\% . Tidak ada hubungan persepsi body image dengan asupan lemak siswi MAN 2 Surakarta . Tidak ada hubungan persepsi body image dengan komposisi lemak tubuh siswi MAN 2 Surakarta.

\section{SARAN}

Disarankan bagi sekolah dapat bekerja sama dengan pihak tenaga kesehatan gizi dan guru BK dalam memberikan edukasi berupa penyuluhan tentang pola makan yang baik dan memberikan penyuluhan tentang dampak lemak tubuh yang berlebih. Bagi siswi mulai mulai memahami persepsi bentuk tubuh yang baik dan menerapkan pola makan yang baik sehingga asupan gizi terutama lemak yang dikonsumsi dapat terpenuhi. Sedangkan bagi peneliti lain perlu dilakukan penelitian lebih lanjut mengenai faktor lain yang mempengaruhi asupan lemak dan komposisi lemak tubuh.

\section{DAFTAR PUSTAKA}

1. Bakar, SA. Kesehatan Reproduksi dan Keluarga Berencana dalam Tanya Jawab. Jakarta : Rajawali Pers. 2014.

2. Rahayu, S dan Fillah F. Citra Tubuh, Pendidikan Ibu, Pendapatan Keluarga, Pengetahuan Gizi, Perilaku Makan dan Asupan Zat Besi pada Siswa SMA. Media Medika Indonesia. Vol 46(3).2012.

3. Sada, MS, Veni H, Djunaedi MD. Hubungan Body Image, Pengetahuan Gizi Seimbang, dan Aktifitas Fisik Terhadap Status Gizi Mahasiswa Politeknik Kesehatan Jayapura. Artikel Penelitian. Politeknik Kesehatan Jayapura. 2012.

4. Kurniawan, M. Hubungan Persepsi Tubuh dengan Gangguan Makan Pada Mahasiswa. Departemen Gizi Masyarakat. Institut Pertanian Bogor. 2014.

5. Kusumajaya, N. Persepsi Remaja Terhadap Body Image (Citra Tubuh) Kaitannya dengan Pola Konsumsi Makan dan Status Gizi. Jurnal Skala Husada. Vol 5(2) 114-25. 2007.

6. Ruslie, R dan Darmadi. Analisis Regresi Logistik Untuk Faktor - Faktor Yang Mempengaruhi Status Gizi Remaja. Majalah Kedokteran Andalas ; No. 1 Vol 36 Januari - Juni 2012.

7. Hartono, A. Terapi Gizi dan Diet Rumah Sakit. Jakarta: EGC. 2006.

8. Almatsier, S. Prinsip Dasar Ilmu Gizi. Jakarta : Gramedia Pustaka Utama. 2009.

9. Lingga, M. Studi Tentang Pengetahuan Gizi, Kebiasaan Makan, Aktivitas Fisik, Status Gizi, dan Body Image Remaja Putri Yang Berstatus Gizi Normal dan Gemuk / Obesitas di SMA Budi Mulia Bogor. Departemen Gizi Masyarakat. Fakultas Ekologi Manusia. Institut Pertanian Bogor. 2011. 
10. Ranasinghe C, Gamage P, Katulanda P, Andraweera N, Thilakarathne S, Tharanga P. Relationship Between Body Mass Index And Body Fat Percentage, Estimated By Bioelectrical Impedance, In A Group Of Sri Lankan Adults: A Cross Sectional Study. BMC Public Health. 13:797. 2013a.

11. Balitbang Kemenkes RI. Riset Kesehatan Dasar(RISKESDAS). Jakarta: Balitbang Kemenkes RI. 2013.

12. Balitbang Kemenkes RI. Riset Kesehatan Dasar(RISKESDAS). Jakarta: Balitbang Kemenkes RI. 2010.

13. Sulistianingsih, H. Gizi Untuk Kesehatan Ibu dan Anak. Yogyakarta: Graha Ilmu. 2011.

14. Aninda. Hubungan Pola Asuh Orangtua Dengan Citra Tubuh Remaja Pada Masa Pubertas Di Wilayah Kelurahan Bintaro Jakarta Selatan( Skripsi). Jakarta. Universitas Negeri Islam Syarif Hidayatullah. 2016.

15. Widyastuti, Y dan Adisarwanto,T. Kesehatan Reproduksi. Fitramaya. Yogyakarta: 2009.

16. Santrock, J. Adolescence Perkembangan Remaja Edisi Keenam. Jakarta: Erlangga. 2003.

17. Stang, J. Assesment of Nutritional Status and Motivation to Make Behavior Changes Among Adolescent. USA : Journal American Diet Association. Vol 102 (3). 2002.

18. Brown. Nutrition Through the Life Cycle (2 nd ed.). USA: Thomso Wadsworth. 2005.

19. Anggraeni, SD. Hubungan Antara Body Image dengan Frekuensi Makan, Jenis Makanan dan Status Gizi Remaja Putri di SMA Negeri 7 Surakarta(Skripsi). Surakarta : Universitas Muhammadiyah Surakarta. 2015.

20. Kusuma, D. Hubungan Aktivitas Fisik, Pengetahuan Gizi dan Body Image Dengan Status Gizi Pada Siswi SMAN 7 Surakarta (Skripsi). Surakarta. Universitas Muhammadiyah Surakarta. 2018.

21. Dienasari, RH. Persepsi Body Image, Kebiasaan Makan Dan Status Gizi Pada Penari Remaja Wanita (Skripsi). Institut Pertanian Bogor. 2016.

22. Aninda. Hubungan Pola Asuh Orangtua Dengan Citra Tubuh Remaja Pada Masa Pubertas Di Wilayah Kelurahan Bintaro Jakarta Selatan (Skripsi). Universitas Negeri Islam Syarif Hidayatullah. 2016.

23. Putri, GP. Hubungan Citra Tubuh (Body Image) dan Pola Konsumsi dengan Status Gizi Mahasiswi Tingkat 1 Jurusan Gizi Poltekkes Kemenkes Padang 2014 (KTI). Padang: Politeknik Kemenkes Padang. 2014.

24. Damayanti, A. Hubungan Citra Tubuh, Aktivitas Fisik dan Pengetahuan Gizi Seimbang dengan Status Gizi Remaja Putri (Skripsi). Surabaya. Univesitas Airlangga. 2016.

25. FAO. Interim Summary of Conclusions and Dietery Recommendations on Total Fat and Fatty Acids. Genewa: WHO Expert Consultation on Fats and Fatty Acids in Human Nutrition. 2008.

26. Sarnblad S, Ulf E, Jan A. Dietary Fat Intake Predicts 1-Year Change in Body Fat in Adolescent Girls With Type 1 Diabetes. Journal Diabetic Care. Department of Pediatrics.University Hospital Vol 29(1227-30). 2006.

27. Suhardjo dan Kusharto. Prinsip-Prinsip Ilmu Gizi. Yogyakarta : Kanisius. 2010.

28. Manuaba, I. Memahami Kesehatan Reproduksi Wanita. Jakarta: EGC. 2008.

29. Williams, Melivin.H. Nutrition for Health, Fitness, and Sport. USA: McGraw-Hill Higher Education. 2002.

30. Sood, A, Pushpa S, Sushma S, Anura V, Kurpad, Sumithra M. BMI and Body Fat Percent Affluent Adolescent Girls In Bangalore City. Sri Lanka: Lady Irwin Collage (University of Delhi). Sri Lanka. Vol 44. 2007.

31. Purba, N. Hubungan Persepsi Body Image, Aktivitas Fisik, dan Konsumsi Makan Sumber Lemak Dengan Status Gizi Guru Wanita(Skripsi). Institut Pertanian Bogor. 2014. 
32. Putri, A. Faktor-Faktor Yang Berhubungan Dengan Pola Konsumsi Makan Pada Siswa Pada Madrasah Ibtidaiyah Unwanul Huda Di Jakarta Selatan(Skripsi). Jakarta : UIN. 2015.

33. Sondari, H. Hubungan Body Image Dengan Perilaku Diet, Konsumsi Pangan dan Status Gizi Remaja Putri Di Perkotaan dan Di Pedesaan (Skripsi). Bogor: Institut Pertanian Bogor. 2013.

34. Chairah, P. Hubungan Gambaran Body Image dan Pola Makan Remaja Putri Di SMA 38 Jakarta (Skripsi). Jakarta: Universitas Indonesia. Jakarta. 2012.

35. Suhardjo. Perencanaan Pangan dan Gizi. Jakarta : Bumi Aksara. 2000.

36. Sediaoetama, A. Ilmu Gizi Untuk Mahasiswa dan Profesi Jilid 1 (Cet.1). Jakarta. Dian Rakyat. 2000.

37. Notoatmojo, S. Promosi Kesehatan dan Ilmu Perilaku. Cetakan I. Jakarta : Rineka Cipta. 2007.

38. Ranasinghe C, Gamage P, Katulanda P, Andraweera N, Thilakarathne S, Tharanga P. Relationship Between Body Mass Index And Body Fat Percentage, Estimated By Bioelectrical Impedance, In A Group Of Sri Lankan Adults: A Cross Sectional Study. BMC Public Health. 13:797. 2013a.

39. Silva, Rita DCR, Rosemeire LF, Ana SR, Mauricio LB. Body Image Dissatisfaction and Dietery Patterns According to Nutritional Status In Adolescents. Journal Pediatria. Universidade Federal de Bahia Departemento Cliencia da Nutricao. 524 Page 7. 2016.

40. Nalurita, E. Hubungan Faktor Reproduksi, Asupan Zat Gizi Dan Aktivitas Fisik Dengan Komposisi Tubuh Wanita Pekerja Berdasarkan Status Menopause (Skripsi). Bogor : Institut Pertanian Bogor. 2015.

41. Dehgan, Mahshid, Noori AD, Anwar TM. Childhood Obesity, Prevalence And Prevention. Canada : Nutrition Journal. McMaster University Hamilton. Vol 4(24). 2005.

42. Zalilah, Khor G L, Mirnalini K, Norimah A K, Ang M. Dietary intake, physical activity and energy expenditure of Malaysian adolescents. Singapore Med Journal. 47(6) : 491. 2006.

43. Thompson D, Karpe F, Lafontan M, Frayn K. Physical activity and exercise in the regulation of human adipose tissue physiology. Department for Health, University of Bath, Bath, UKPhysiol Rev; 92 : 157-191. 2012.

44. WHO. Diet, Nutrition and The Preventive of Chronic Disease. Geneva : WHO Technical Report Series 854. 2003.

45. Arranir, Mohammad, Desmawati, Dinda A. Hubungan Kebiasaan Sarapan dan Asupan Kalori dengan Persentase Lemak Tubuh pada Mahasiswa Prodi Profesi Dokter Fakultas Kedokteran Universitas Andalas Angkatan 2013-2015. Padang : Jurnal Kesehatan FK Andalas. Vol. 265270. 2017.

46. Nix, S. William's Basic Nutrition \& Diet Therapy, Twelfth Edition. USA : Elsevier Mosby Inc, 2005.

47. Habibaturohmah dan Deny YF. Hubungan Konsumsi Air, Asupan Zat Gizi dan Aktivitas Fisik Remaja Putri. Journal of Nutritional Collage. Program Studi Ilmu Gizi Fakultas Kedokteran Universitas Diponegoro. Vol 3(595-603). 2014.

48. Santoso, BI, Hardinsyah, Siregar P, Pardede SO. Air Bagi Kesehatan. Jakarta: Centra Communications. 2011.

49. Oktaviani, WD, Lintang DS , M. Zen R. Hubungan Kebiasaan Konsumsi Fast Food, Aktivitas Fisik, Pola Konsumsi, Karakteristik Remaja Dan Orang Tua Dengan Indeks Massa Tubuh (IMT) (Studi Kasus Pada Siswa Sma Negeri 9 Semarang Tahun 2012). Jurnal Kesehatan Masyarakat. Universitas Diponegoro. Vol 1(2) : 542-553. 2012.

50. Gibson, R. Principles of Nutritional Assessment Second Edition. New York : Oxford University Press Inc. 2005. 
51. Zeng, Q, Sheng YD, Xiao NS, Jing X dan Yi C. Percent Body Fat Is A Better Predictor Of Cardiovascular Risk Factors Than Body Mass Index. Brazilian Journal of Medical and Biological Research. 45(7): 591-600. 2012. 